YAK 347.447 .52

DOI https://doi.org/10.32837/chc.v0i43.443

Приленський Ігор Генрихович,

аспірант кафедри цивільного права

Національного університету “ОАеська юридична академія"

ORCID ID: 0000-0002-0511-3798

\title{
ОСОБЛИВОСТІ ЦИВІЛЬНО-ПРАВОВОЇ ВІДПОВІДАЛЬНОСТІ ПАСАЖИРІВ ЗА ДОГОВОРОМ ПЕРЕВЕЗЕННЯ ПОВІТРЯНИМ ТРАНСПОРТОМ В УКРАЇНІ
}

Постановка проблеми. Відповідальність як категорія циві^ьного права $€$ оАнією $з$ найбільш складних та найважливіших. Наразі існує багато наукових робіт, які присвячені інституту віАповіАальності загалом чи будь-яким його склаАникам.

У початковий періоА АосліАжень цієї сфери вчені намагалися сформулювати основоположні засади зазначеної категорії і мише набагато пізніше взялися за визначення самого поняття цивільно-правової віАповіАальності.

СліА зазначити, що Аля правопорушника у цивільно-правових віАносинах, тобто боржника, негативним наслідком $€$ його цивільно-правова віАповіАальність, віАповіАно АО якої АО порушника в інтересах зацікавленої особи, тобто креАитора, застосовуються встановлені законом або умовами Аоговору санкції майнового характеру у вигляАі віАшкоАування Збитків, виплати неустойки або пені, штрафних санкцій тощо. Аля застосування зазначених санкцій, переАбачених цивільно-правовою віАповіАальністю, піАставами виступають віАповіАні норми права і складу правопорушення. Зокрема, віАповідно Ао положень законодавства такими підставами є: протиправна поведінка осіб, учасників цивільних правовіАносин; негативний результат у вигляАі завдання шкоди; причинний зв'язок між протиправною поведінкою і настанням шкоди; вина особи, яка вчинила протиправні Аії, що призвели Ао заподіяння шкоАи.

Водночас якщо розгляАати цивільно-правову віАповідальність у сфері транспортної Аіяльності, то вона має певні особливості, аАже може застосовуватися й за віАсутності вини особи, якщо протиправність повеАінки такої особи буде
Аоведена, а вина буде припускатися. НаприклаА, положення ст. 68 Закону України «Про автомобільний транспорт" передбачає "віАповіАальність залізниць за незбереження вантажу, багажу, вантажобагажу за умови доведення факту втрати, нестачі, псування, пошкодження в результаті незалежних віА залізниць причин" [1]. Тобто вина припускається, а ії віАсутність треба Аовести.

СліА також звернути увагу на те, що в сфері транспортних віАносин, згіАно з цивільним законодавством України, цивільно-правова відповіАальність носить компенсаційний характер, аАже метою такої віАповіАальності $\epsilon$ відновлення порушених майнових прав учасників цивільних правовіАносин у транспортній галузі, а отже, розмір відшкодування завданої шкоди не може перевищувати розмір завданих збитків [1]. ОАнак зазначена віАповідальність буде залишатися обмеженою, аАже неотримані доходи відшкодовуватися не будуть. Визначену позицію, на нашу Аумку, можна пояснити тим, що транспортна галузь не віАноситься Ао прибуткової виробничої сфери, тоді як Аля розвитку економіки та забезпечення обороноздатності держави велике значення має продовження процесу виробництва товарів, а отже, законодавець вважає доцільним застосування обмеженої цивільно-правової віАповідальності Аля транспортної галузі цивільно-правових віАносин.

Метою статті $€$ науковий аналіз загальних положень законодавства України Аля визначення особливостей цивільно-правової віАповіАальності пасажира в сфері перевезень повітряним транспортом згідно з законодавством України. 
Стан Аослідження теми. Проблеми цивільно-правової віАповіАальності АосліАжувалися такими вченими, як С.М. Бервено, М.І. Брагінський, А.А. Верховець, В.П. Грибанов, А.А. Аонська, О.С. Іоффе, І.С. Канзафарова, О.О. ОтраАнова, В.А. Тархов, А.^. Ткачук, С.А. Чванкін, а питання відповідальності у сфері перевезень висвітлювались у працях таких АосліАників, як С.С. Алєксєєв, А.Г. Артемюк, С.М. Бервено, М.К. Галянтич, В.П. Грибанов, О.В. Азера, Г.В. Самойленко, О.М. Нечипуренко, Р.Б. Шишка.

ВиклаА основного матеріалу АосліАження 3 повним обґрунтуванням отриманих наукових результатів. У галузі транспортної Аіяльності існує багато особливостей цивільно-правової віАповіАальності, оАнією з яких $€$ неоАнаковість Умов відповідальності процесу перевезення. ВіАповіАальність перевізника, окрім випадків завдання шкоАи внасліАок спричинення шкоАи зАоров'ю пасажира або його загибелі, настає віАповіАно Ао положень Правил транспортного законодавства. Також за нормами транспортного законоАавства відповідальність переА перевізником за порушення несе віАправник, який також несе віАповіАальність і перед отримувачем, однак за нормами цивільного законодавства. Зазначене дає піАстави стверАжувати, що в такому разі виникає особливий поряАок розгляАу майнових спорів із питань порушень у транспортній сфері, зокрема в перевізному процесі. Водночас особливістю цивільно-правової віАповіАальності у транспортній галузі $€$ й те, що віАносинам у транспортній сфері притаманний особливий порядок висування претензій із метою задоволення вимог потерпілої сторони, що $є$ віАмінним віА усталеного порядку вирішення певних спорів у господарській Аіямьності.

Отже, зазначені визначення та особливості цивільно-правової віАповідальності за порушення зобов'язань у транспортних перевезеннях Аають піАстави відокремлювати таку віАповіАальність віА загальної цивільно-правової віАповіАальності. Вказане $€$ наслідком нашарування суто галузевих норм, що враховують специфіку транспортної Аіяльності та їі розвиток, можливості покриття збитків, заподіяних користувачам, та соціальну цінність у сфері економіки, на загальні цивільно-правові норми. Отже, всім комплексним галузям права притаманна наявність спеціальних правових норм.

Практика свідчить, що майже кожен Аругий укладений Аоговір порушується на стаАії його виконання. Іноді порушення $€$ незначними або ж сторони знають, що їм вАасться врегулювати свої віАносини. У тих випадках, коли сторони не можуть Аійти згоди, законом надається можливість застосувати насліАки порушення зобов'язань [2, с. 128].

Порушення зобов'язання проявляється через вчинення боржником протиправних дій, або, як ще говорять, протиправну повеАінку боржника. Поведінка особи визнається протиправною, якщо така поведінка порушує норми права, незалежно віА того, знала чи не знала особа про неправомірність своєї повеАінки. Інакше кажучи, у понятті протиправності знаходить віАображення тільки факт об'єктивної невіАповіАності повеАінки учасника цивільного обороту вимогам законоАавства. Нормами цивільного законодавства встановлені різні вимоги до повеАінки учасників цивільного обороту.

Таким чином, у разі виникнення зобов'язання з алміністративного акта критерієм протиправності $€$ невіАповіАність поведінки боржника змісту цього аАміністративного акта. Якщо зобов'язання виникає 3 Аоговору, то протиправною визнається поведінка боржника, який порушує умови Аоговору. Якщо ж в основі зобов'язання лежить оАносторонній правочин, то протиправною буде поведінка боржника, яка не віАповіАає його умовам. Протиправна поведінка може виражатися у вигляАі протиправної Аії або протиправної безАіяльності. Бездіяльність мише в тому випадку стає протиправною, якщо на особу покладено юриАичний обов'язок Аіяти у віАповіАній ситуації. Обов'язок Аіяти може вихоАити з умов уклаАеного Аоговору.

Отже, Аії боржника набувають протиправного характеру, якщо вони або прямо заборонені законом чи іншим правовим актом, або суперечать закону чи іншому правовому акту, Аоговору, оАносторонньому правочину тощо.

ВіАповіАно Ао Аоговору повітряного перевезення всі учасники повинні Аотримуватися загальних правил, про які не повинні забувати ні перевізники, ні їхні клієнти. Недотримання цих правил може обернутися Аодатковими проблемами і непередбачуваними витратами. Роль цивільно-правового Аоговору значно посилюється у самостійній організації господарської Аіяльності суб'єктів товарно-грошових віАносин. Зазначене свіАчить про зростаючу соціальну цінність цивільного права у правовій державі і визначає його місце в системі правових галузей [3, с. 59].

Аійсність Аоговору, як віАомо, залежить віА таких чинників, як зАатність сторін до його укла- 
Аання, відповідність їх волі та волевиявлення, Аотримання форми Аоговору, спрямованість його на настання реальних правових насліАків, віАповідність Аоговору вимогам законодавства та моральним засадам суспільства. Нездійснення платежу за Аоговором є порушенням умов виконання Аоговору, а не його недійсністю. Порушення умов виконання Аоговору та його недійсність спричинюють різні насліАки. ВоАночас сторони, які укладають договір, мають право обумовити настання або зміну прав та обов'язків обставиною, щодо якої невідомо, настане вона чи ні (відкладальна обставина) [4, с. 42]. ВідповіАно до ст. 212 Цивільного кодексу України (Аалі - ЦК України) в разі недобросовісного перешкоджання стороною, якій невигідне настання відповідної обставини, відкладальна обставина вважається такою, що настала.

Суб'єктивні права, як і право, мають певні межі. Їх можна назвати природними межами суб'єктивних прав, або межами зАійснення прав.

Зокрема, на Аумку Є.О. Харитонова, обсяг і межі цього права значною мірою визначають зміст цивільної правосуб'єктності, яка своєю чергою створює необхідні умови Аля набуття і реалізації різних суб'єктивних прав [5, с. 44].

За Аоговором перевезення пасажира, відповідно до ч. 1 ст. 910 ЦК України, "одна сторона (перевізник) зобов'язується перевезти іншу сторону (пасажира) Ао пункту призначення, а в разі зАавання багажу - також Аоставити багаж Ао пункту призначення та видати його особі, яка має право на одержання багажу, а пасажир зобов'язується сплатити встановлену плату за проїзА, а в разі зАавання багажу - також за його перевезення" [12].

Аосить Аетально описані права й обов'язки перевізника та пасажира у Правилах повітряних перевезень. Але і в цьому випадку має місце певне нівелювання позитиву, зумовлене тим, що це рівень підзаконних нормативно-правових актів, які можуть бути скасовані, що не сприяє захисту прав пасажирів та врегульованості правовіАносин із повітряного перевезення.

За наявності у пасажира особливих вимог Ао перевезення за станом здоров'я інформація про необхіАні умови зАійснення повітряного перевезення повинна бути надана перевізнику заздалегіАь, на загальних підставах віА трьох Ао однієї Аоби, залежно віА ситуації, оскільки Ао основних обов'язків перевізника належить створення безпечних і комфортних умов Аля пасажира [6, с. 187].
3 метою захисту прав пасажира як сторони Аоговору мають бути закріплені імперативи разом із механізмом їхньої реалізації, зокрема, на рівні ЦК України та спеціальних законів. Свого часу висловлювалася Аумка про те, що межі $€$ невіА'ємною властивістю будь-якого суб'єктивного права, бо за відсутності таких меж право перетворюється на свою протилежність - свавімля, і таким чином взагалі перестає бути правом [7]. При цьому віАзначалося, що визначення меж зАійснення цивільних прав не є обмеженням цих прав (їх позбавленням).

Керуючись законодавством України, до суб'єктів правовіАносин за договором повітряного перевезення належать авіаційний перевізник і пасажир.

Ао обов'язків пасажира відноситься оплата за надання послуги повітряного перевезення. Пасажир своєю чергою завжАи має право відмовитися віА повітряного перевезення та отримати назад сплачену суму коштів. Повернення повної чи часткової виплати зАійснюється в порядку, встановленому законодавством України. ВіАмова авіаперевізника визначається як відмова у перевезенні пасажира або його багажу рейсом, незважаючи на його присутність Аля посаАки на борт. ПіАстави Аля віАмови у посаАці чітко визначені Повітряним кодексом України (далі - ПК України). Ао таких підстав можна віАнести охорону зАоров'я, гарантування безпеки, неналежне оформлення необхінної Аля перевезення Аокументації (паспорта, візи, квитка тощо) [8, с. 75].

Відповідно до Правил повітряних перевезень пасажирів і багажу “пасажир зобов'язаний зберігати квиток та інші перевізні документи до завершення процесу перевезення, а в разі виникнення у нього претензії - Ао часу її вирішення. Квиток та інші перевізні Аокументи, що видаються пасажиру, повинні бути преА'явлені на першу вимогу уповноважених осіб перевізника" [9].

Також сліА зазначити, що перевізник може відмовити у перевезенні чи подальшому перевезенні пасажира (багажу) з метою гарантування безпеки польоту та виконання вимог застосованих законів або на підставі власних обґрунтованих рішень.

Окрім Аотримання законних прав, що випливають з Аоговору повітряного перевезення, пасажир водночас повинен Аодержуватися чинних на віАповіАному транспорті правил та бережливо користуватися майном перевізника. 3 метою забезпечення безпеки польотів, охорони життя і зАоров'я пасажирів та членів екіпажа піА час повітряних 
перевезень зАійснюється огляА пасажирів, їхньої ручної поклажі та багажу [4, с. 41]. Такий огляА проводиться в аеропорту чи міському аеровокзалі. Якщо пасажир в аеропорту віАмовляється віА огляду багажу, перевізник має право розірвати Аоговір. За розірвання Аоговору повітряного перевезення перевізник повертає плату за перевезення за вирахуванням встановленого збору.

Перевізник має право вимагати віА пасажира преА'явлення уповноваженим особам перевізника, представникам відповідних державних органів наявних Аокументів на виїзА, в'їзА або транзит, належних Аовідок про стан зАоров'я та інших Аокументів, що вимагаються віАповіАно до законодавства. Перевізник має право самостійно зробити і залишити в себе копії або в будьякий інший спосіб зафіксовані дані, що містяться у наданих документах.

За перевізником закріплюється право віАмовити в перевезенні пасажиру, який не дотримувався чинних норм права, неналежно оформив Аокументи, в якого відсутні віза, кошти, квиток у зворотному напрямку тощо. Перевізник має право змінювати тип повітряного судна без повіАомлення про це пасажира та не відповіАає за помилки й упущення в розклалах руху.

У разі затримки в перевезенні пасажир має право віАмовитися віА перевезення та вимагати віА перевізника, з вини якого сталася затримка, повного повернення коштів, сплачених за нездійснене перевезення, та компенсацію за затримку, якщо вона перевищила Аопустимі строки.

Якщо затримка мала місце понаА 3 години, перевізник повинен надати пасажиру за встановленими нормами безкоштовне харчування, проживання в готелі тощо. Водночас Аодаткові витрати пасажира понаА норми, встановлені перевізником, пасажиру не відшкодовуються.

Укладаючи Аоговір перевезення повітряним транспортом, пасажири певним чином потрапляють у залежність віА перевізника. Це пов'язане з правовою природою Аоговору, який має публічний характер. Окрім того, більшість пасажирів не Аосить обізнані у своїх правах на випадок скасування рейсу чи його затримки. В результаті цього порушуються права пасажирів на вчасне перевезення. Пасажири часто стикаються 3 певними перепонами в разі преА'явлення претензій безпосередньо авіаперевізникам. Нерідко такі скарги необґрунтовано віАхиляються.

Щодо віАповіАальності за Аоговором перевезення повітряним транспортом, то вона має свої особливості в правовому регулюванні. Така осо- бливість зумовлена насамперед наявністю спеціального національного законодавства, а саме: ПК України і Прави^ повітряних перевезень та обслуговування пасажирів і багажу. Також варто зазначити, що міжнародні акти, які регулюють міжнародні перевезення та закріплюють безпеку авіаційних перевезень, мають значний вплив на становлення галузі повітряних перевезень [10].

Сторони Аоговору повітряного перевезення за невиконання або неналежне виконання своїх обов'язків за договором або тих, що випливають з факту укладення Аоговору, несуть матеріальну відповідальність.

ВіАповіАно, пасажир несе відповідальність за будь-яку шкоду, завдану авіаперевізнику або особам, перед якими авіаперевізник несе відповіАальність.

Наслідком такого є: по-перше, порушення, невиконання або неналежне виконання прави^ польотів і перевезень; по-Аруге, неповіАомлення перевізнику інформації або повідомлення неправдивої інформації про свій багаж.

Пасажир самостійно несе віАповіАальність за отримання всіх потрібних Аокументів: віз, Аозволів тощо. Своєю чергою перевізник, віАповіАно Ао Правил повітряних перевезень, не нестиме відповіАальність переА пасажиром за те, що пасажир не одержить такі Аокументи чи не виконає такі застосовані закони [11, с. 428].

Наразі цивільне законодавство не містить положень, в яких визначається відповіАальність пасажира за порушення правил перевезення. ОАнак у ст. 920 ЦК України зазначено, що “в разі порушення зобов'язань, які випливають із Аоговору перевезення, сторони несуть віАповіАальність, встановлену за домовленістю сторін, якщо інше не визначено цим Кодексом, іншими законами, транспортними кодексами (статутами)" [12].

3 огляду на це віАповіАальність пасажира за порушення правил перевезення має зазначатися у Аоговорі перевезення пасажирів та багажу. Такий Аоговір є публічним у разі користування пасажиром транспортом загального користування. Аоговір вважається укладеним із моменту придбання пасажиром квитка або багажної квитанції, Аія Аоговору завершується, коли пасажир прибув у місце призначення та залишив транспортний засіб.

ОАнаквсе ще не повністю вирішенимє питання відповідальності пасажира за порушення правил перевезення. Відсутність у пасажира посадкового квитка робить неможливим укладення договору між ним і перевізником. Але в Україні на 
автобусних рейсах поширена практика перевезення пасажирів без квитка чи іншого документа, що підтверджує право на поїзАку. В таких випаАках виникає спірне питання про відповідальність перевізника, якщо пасажиру буде завдано моральну чи матеріальну шкоду, оскільки договір не є укладеним.

Аналіз законодавчої бази, а саме транспортних статутів, кодексів, Правил перевезень пасажирів, свідчить про віАсутність у законодавстві єАиних підходів до регулювання цивільно-правової віАповідальності пасажирів піА час перевезення різними видами транспорту. На сучасному етапі правове регулювання відповідальності за шкоду, заподіяну піА час повітряного перевезення, на Аумку низки авторів, потребує вАосконалення, більш детальної регламентації.

Висновки з АосліАження та перспективи подальших розвіАок у цьому напрямі. Цивільно-правова відповідальність $€$ негативним наслідком Аля правопорушника у цивільно-правових відносинах, тобто боржника, віАповіАно Ао якої стосовно порушника в інтересах зацікавленої особи застосовуються встановлені законом або умовами Аоговору санкції майнового характеру.

Щодо цивільно-правової віАповідальності у сфері транспортної діяльності, то вона має певні особливості, аАже може застосовуватися і за віАсутності вини особи, якщо протиправність пове-
Аінки такої особи буде доведена, а вина буде припускатися.

Через те що метою віАповідальності у сфері транспортних правовіАносин є віАновлення порушених майнових прав учасників правовідносин, вона носить компенсаційний характер. Визначено, що, віАповіАно Ао Аоговору повітряного перевезення, всі учасники повинні Аотримуватися загальних правил. Недотримання умов Аоговору може обернутися додатковими проблемами і непередбачуваними витратами.

Встановлено, що в разі порушення зобов'язання, яке виникає з Аоговору, протиправною визнається поведінка боржника, який порушує умови Аоговору.

Проаналізувавши норми законодавства, АохоАимо висновку, що пасажир самостійно несе віАповіАальність за отримання всіх потрібних Аокументів: віз, Аозволів, тощо. ВіАповідальність пасажира за порушення правил перевезення має зазначатися в Аоговорі перевезення пасажирів та багажу.

Аоговір вважається укладеним з моменту приАбання пасажиром квитка або багажної квитанції, Аія Аоговору завершується, коли пасажир прибув у місце призначення та залишив транспортний засіб. Аля забезпечення належного виконання Аоговору повітряного перевезення необхіАно здійснювати послідовні і взаємопов'язані дії, що обумовлені у Аоговорі перевезення.

\section{NITEPATYPA:}

1. Про автомобільний транспорт : Закон України від 23 лютого 2006 р. Відомості Верховної Ради Украӥни. 2006. № 32 . Ст. 273.

2. Чванкін С.А. Правові наслідки порушення зобов'язань. Актуальні проблеми держави і права. 2008. С. 128-132.

3. Самойленко Г.В. Цивільно-правова характеристика договору перевезення пасажира як споживчого договору. Bicник 3 anoрізького національного університету. № 3. С. 58-65.

4. Артемюк Л.Г. Особливості договору перевезення пасажирів і багажу повітряним транспортом. Право Украӥни. 2012 . № 2. C. $41-45$.

5. Харитонов Є.О. Правове регулювання перевезень в Україні : навч. посібник. Харків : Освіта, 2006. 250 с.

6. Бортник Н.П. Договір перевезення пасажирів та багажу в міжнародному приватному праві. Вісник Національного університету «Львівська політехніка». 2014. № 807. С. 187-191.

7. Грибнов В.П. Захист прав за договором перевезення. URL: http://www.twirpx.com/file/1740303/.

8. Оніщенко О.В. Договір повітряного перевезення: деякі цивільно-правові аспекти. Юридичний вісник. 2011. № 4 (13). C. $75-81$.

9. Правила повітряних перевезень вантажу : Наказ Міністерства інфраструктури України № 728 від 30 листопада 2012 р. Офіційний вісник Украӥни. № 4.

10. Конвенція про шкоду, заподіяну іноземними повітряними суднами третім особам на поверхні. URL: http://www.aviadocs. net/icaodocs/Docs/7364_ru.pdf.

11. Табачник Д.В. Повітряне право : навч. посібник. Дрогобич : Коло, 2011. 550 с.

12. Цивільний кодекс України : Закон України від 16 січня 2003 р. Відомості Верховної Ради України. 2003. № 40-44. Ст. 356.

\section{Приленський Ігор Генрихович \\ ОСОБАИВОСТІ ЦИВІАЬНО-ПРАВОВОЇ ВІАПОВІАААЬНОСТІ ПАСАЖИРІВ ЗА АОГОВОРОМ ПЕРЕВЕЗЕННЯ ПОВІТРЯНИМ ТРАНСПОРТОМ В УКРАЇНІ}

У статті надано загальну характеристику цивільно-правової відповідальності пасажирів за договором перевезення повітряним транспортом в Україні. Визначено, що цивільно-правова відповіАальність настає за порушення зобов'язання, а воно проявляється через вчинення боржником протиправних дій, або, як ще говорять, протиправну повеАінку боржника. Протиправною визнається така поведінка, яка порушує норму права, незалежно віА того, знав чи не знав правопорушник про неправомірність своєї повеАінки. 
Цивільно-правова відповідальність застосовується за порушення зобов'язань сторонами договору повітряного перевезення. ПіАстави і випадки застосування цивільно-правової відповідальності за порушення транспортних зобов'язань регламентуються ЦК України, Законом України “Про транспорт» та іншими законами, транспортними кодексами і статутами, а також відомчими актами Міністерства інфраструктури України.

Розглянуто особливості віАповіАальності пасажира за порушення правил перевезення. ВіАповіАальність за порушення зобов'язань із перевезення має специфіку, що віАрізняє ії віА звичайної віАповіАальності за порушення зобов'язань. Пасажир також несе відповідальність за будь-яку шкоду, завдану авіаперевізнику або особам, перед якими авіаперевізник несе відповідальність.

Встановлено, що в разі порушення зобов'язання, яке виникає з Аоговору, протиправною визнається повеАінка боржника, який порушує умови договору. Наголошується, що пасажир самостійно несе віАповіАальність за отримання всіх потрібних документів: віз, дозволів тощо. ВідповіАальність пасажира за порушення правил перевезення має зазначатися у договорі перевезення пасажирів та багажу.

Аоговір вважається укладеним з моменту придбання пасажиром квитка або багажної квитанції, дія договору завершується, коли пасажир прибув у місце призначення та залишив транспортний засіб. Із метою забезпечення належного виконання договору повітряного перевезення необхідно зАійснювати послідовні і взаємопов'язані дії, що обумовлені у Аоговорі перевезення.

Встановлено, що немає єАиного піАходу Ао визначення цивільно-правової віАповіАальності, а також віАсутній основний піАхіА АО розуміння її сутності.

Ключові слова: Аоговір перевезення пасажира, Аоговір, пасажир, зміст Аоговору, зміст договору перевезення, права та обов'язки пасажира, відповідальність сторін.

\section{Prilensky Ihor}

FEATURES OF CIVIL LIABILITY OF PASSENGERS UNDER THE CONTRACT OF CARRIAGE BY AIR IN UKRAINE

The presented article provides a general description of the civil liability of passengers under the contract of carriage by air in Ukraine. It is determined that civil liability arises for breach of obligation, and it is manifested through the commission of the debtor's illegal actions, or, as it is said, the debtor's illegal behavior. Such conduct that violates the rule of law is considered illegal, regardless of whether the offender knew or did not know about the illegality of his behavior.

Civil liability is applied for breach of obligations by the parties to the contract of carriage by air. The grounds and cases of application of civil liability for violation of transport obligations are regulated by the Civil Code of Ukraine, the Law of Ukraine "On Transport" and other laws, transport codes and statutes, as well as departmental acts of the Ministry of Infrastructure of Ukraine.

Features of responsibility of the passenger for violation of rules of transportation are considered. Liability in transportation obligations has a specificity that distinguishes it from the usual liability for breach of obligations. The passenger is also liable for any damage caused to the air carrier or persons to whom the air carrier is liable.

It is established that the obligation arising from the contract, the behavior of the debtor that violates the terms of the contract is considered illegal. It is emphasized that the passenger is responsible for obtaining all necessary documents: visas, permits, etc. The passenger's liability for violation of the rules of carriage must be specified in the contract of carriage of passengers and luggage.

The contract is considered concluded from the moment the passenger purchases a ticket or luggage receipt, the contract expires when the passenger arrives at the destination and leaves the vehicle. In order to ensure the proper performance of the contract of carriage by air, it is necessary to carry out consistent and interrelated actions stipulated in the contract of carriage.

It is established that there is no single approach to the definition of civil liability, and there is no basic approach to understanding its essence.

Key words: passenger transportation agreement, agreement, passenger, content of the agreement, content of the transportation agreement, rights and obligations of the passenger, responsibility of the parties. 